\title{
Vascular Endothelial Growth Factor A 165 Isoform
}

National Cancer Institute

\section{Source}

National Cancer Institute. Vascular Endothelial Growth Factor A 165 Isoform. NCI

Thesaurus. Code C126413.

Vascular endothelial growth factor A 165 isoform (191 aa, $22 \mathrm{kDa}$ ) is encoded by the human VEGFA gene. This protein plays a role in the positive regulation of both cell proliferation and angiogenesis. 